\title{
The Relationship between Interpersonal Emotion Regulation and Interpersonal Competence Controlled for Emotion Dysregulation
}

\author{
Asude Malkoç ${ }^{1}$, Meltem Aslan Gördesli ${ }^{1}$, Reyhan Arslan ${ }^{1}$, Ferah Çekici $^{1} \&$ Zeynep Aydın Sünbül ${ }^{1}$ \\ ${ }^{1}$ School of Guidance and Psychological Counseling, Istanbul Medipol University, Istanbul, Turkey \\ Correspondence: Asude Malkoç, School of Guidance and Psychological Counseling, Istanbul Medipol University, \\ Istanbul, Ataturk St. No: 40 Floor 4, Turkey. E-mail: amalkoc@ medipol.edu.tr
}

Received: December 11, 2018

Accepted: January 13, 2019

Online Published: January 21, 2019

doi:10.5430/ijhe.v8n1p69

URL: https://doi.org/10.5430/ijhe.v8n1p69

This study was presented at INESSRC (International Necatibey Education and Social Sciences Research Congress) held in Ballkesir, TURKEY in October 2018.

\begin{abstract}
The aim of this study is to examine the role of interpersonal emotion regulation on interpersonal competency when controlled for emotion dysregulation. The sample of the study consists of 342 ( 235 female; 107 male) undergraduate students attending to the various departments of a private university in Turkey. The average age of participants was 20.81 ( $\mathrm{SD}=2.29)$. The Interpersonal Emotion Regulation Scale, Difficulties in Emotion Regulation Scale and Interpersonal Competency Scale were used. Analyses were conducted through the SPSS 20 (IBM, 2011). Results of hierarchical regression analysis revealed that interpersonal emotion regulation and emotion dysregulation seem to predict interpersonal competency. After controlling for the effect of emotion dysregulation, interpersonal emotion regulation alone explains $18 \%$ of the overall variance in interpersonal competency. Interpersonal emotion has the highest contribution on interpersonal competency followed by emotion dysregulation.
\end{abstract}

Keywords: interpersonal emotion regulation, interpersonal competency, emotion dysregulation, university students

\section{Introduction}

Humans are undoubtedly social animals. Thus, one of our most basic needs pertains to the formation of positive social relationships. The maintenance of positive social relationships fulfills the need for belonging and acceptance. Baumeister and Leary (1995) assert that humans are strongly motivated to have long-lasting and permanent interpersonal relationships. In the period within which adulthood beckons, particularly, covering the ages of 19-26, individuals make decisions that will fundamentally alter major aspects of their lives, whether in terms of their careers or their world view (Arnett, 2000). This period is dogged by a series or combination of major expectations, including but not limited to gaining of autonomy, development of an identity, adaptation to the environment, educational pursuits, achievement of independence, and sparking of healthy intimate relationships (Atak \& Çok, 2010). Meanwhile, young adults themselves endeavor to enrich their life experiences through interpersonal relations, adapt to their social environment effectively, and strengthen the existing relations (Şahin \& Gizir, 2014). One of the most important concepts governing young peoples' ability to develop positive social relations (and no less, to maintain them) is social competence.

\subsection{Literature Review}

Numerous studies deal with social competence in relation with social skills (Hudson \& Ward, 2000) - producing various definitions. According to Foster and Ritcher (1979), social competence means fulfilling social purposes such as making friends, gaining popularity among friends, and experiencing social interaction. Rose-Krasnor (1997) defines social competence as the act of being active in social interactions. Topping, Bremner and Holmes (2000), meanwhile define it as the ability to use feelings, thoughts and behavior in coordination when fulfilling social tasks such as initiating and maintaining relationships. According to Mallinckrodt's (2000) definition, social competence refers to all skills necessary in building and maintaining fulfilling and supportive relationships.

As can be seen in these definitions, social competence is entirely associated with such concepts as managing social, cognitive, and behavioral skills and relations. Buhrmester, Furman, Wittenberg \& Reis (1988) stress that social 
competence should be defined and re-addressed in terms of its constituents. Therefore, they advocate the use of interpersonal competence rather than social competence, as social interactions also entail close relations, friendship relations, and interpersonal skills.

Interpersonal competence means having healthy relationships through initiating and sustaining interpersonal relationships, overcoming adverse experiences in these relationships, receiving and providing social support, and deriving satisfaction from social relationships (Şahin \& Gizir, 2014). According to Buhrmester, Furman, Wittenberg, and Reis (1988), interpersonal competence has five dimensions: initiating a relationship, asserting influence, self-disclosure, emotional support, and resolving conflict. Initiating a relationship involves willingness to build relationships with others; asserting influence involves defense of one's own rights in interpersonal relationships; self-disclosure entails sharing of feelings and ideas with others; emotional support relates to consoling others at problematic times, and resolving conflict refers to coping with conflicts in social relationships. Existing research demonstrates that individuals with high interpersonal competence tend to be more agreeable in social relations, build close friendships more easily (Buhrmester, 1990), and experience greater inner satisfaction (Buhrmester, 1998).

The ability to regulate interpersonal emotions is considered one of the factors influencing people's interpersonal competence. Social processes play an important role in expressing and experiencing emotions (Hofmann, 2014). Higgins \& Pittman (2008) state that emotion regulation is critical for human's socialization process; similarly, Eisenberg, Fabes, Guthrie and Reiser (2000) posit that emotion regulation is a social process by which people are influenced by other's reactions.

During the process of emotion regulation, individuals tend to harness its interpersonal aspects specifically (Williams, Morelli, Ong \& Zaki, 2018). Interpersonal emotion regulation is a process through which a person regulates their emotional reactions to various stressful experiences within the framework of their social relations with other people (Hofmann, Carpenter \& Curtis, 2016; Zaki \& Williams, 2013). In this process, the existence of strong social bonds and social support (Berscheid, 2003; Coan, Schaefer \& Davidson, 2006), sharing the negative emotional experiences with others (Rime, 2007, 2009), and having other people to provide comfort, is remarkably conducive of reducing an individual's negative feelings (Niven, Totterdell, \& Holman, 2009).

Zaki and Williams (2013) assert that any social interaction is effective in triggering the interpersonal emotion regulation process, which is twofold in its nature: intrinsic and extrinsic. In the former, a person initiates social interaction to alter the emotions they experience and support extended by someone else helps the emotion regulation process. In the latter, however, a person has an active role in and sought for somebody else's emotion regulation process (Zaki \&Williams, 2013).

Some people often seek others' support to cope with their negative feelings under stressful circumstances (Williams, Morelli, Ong \& Zaki, 2018). That is, as these people have difficulty in regulating their emotions by themselves, they share their emotions with others to overcome the difficult times. Such sharing leads to a wholesome physical and mental state (Marroquin, Tennen \& Stanton, 2017).

Difficulties in emotion regulation should be approached as a matter of controlling impulsive behaviors against negative emotions, maintaining goal-oriented behaviors, and accessing to adaptive emotion regulation strategies (Gratz \& Roemer 2004; Neuman, van Lier, Gratz \& Koot, 2010). Gratz \& Roemer (2004) suggest six dimensions causing the emotion regulation difficulties: lack of emotional awareness (awareness), inability to recognize emotional responses (clarity), difficulty to accept the emotional response (acceptance), difficulty to transfer to goal-oriented action (goal), limited retention of emotion regulation strategies (strategy), and incapability of controlling emotions (impulse). Individuals suffering from emotion regulation difficulties are expected to encounter difficulties within the scope of these specific dimensions.

Research shows that there is a significant positive relationship between difficulty in emotion regulation and general anxiety disorders (Roemer, Lee, Salters-Pednault, Erisman, Mennin \& Orsillo, 2009; Werner \& Gross, 2009), social anxiety (Werner, Goldin, Ball, Heimberg \& Gross, 2011), post-traumatic stress disorder (Ehring \& Quack, 2011), and personality disorders (Salsman \& Linehan, 2012). Thus, it can be concluded that difficulty in emotion regulation is a major variable affecting the psychological well-being of a person. Mc Laughlin, Hatzenbuehler and Phil (2008) point out that emotion regulation difficulty encountered in a stressful situation has an adverse effect on mental health.

The transition to university life can be a stressful process for many students for all sorts of reasons, not least the sudden separation from family, the trials of academia itself, difficulties experienced in intimate relationships, and adjusting to a new environment generally. Students have to cope with such problems throughout their time in education and beyond. Not only the sudden environmental change, but the coping process in response to it can be 
emotionally stressful for many, to the extent the ability to regulate emotion suffers. At such times, what is needed most is social support. Access to social support is crucial in helping young people to cope with stressful situations and regain their emotional mental health. To this end, the present study intends to analyze the role of university students' interpersonal emotion regulation skills in their interpersonal competence when emotion regulation difficulty is controlled. The study focuses on the effect of difficulty in emotion regulation, as this is thought to disrupt the interaction between interpersonal emotion regulation and interpersonal competence.

\subsection{Research Questions}

The aim of this study is to examine the role of interpersonal emotion regulation on interpersonal competency when controlled for emotion dysregulation. To this end, the following research questions were posed:

1.2.1 What are the relationships between interpersonal emotion regulation, interpersonal competency and emotion dysregulation?

1.2.2 Does interpersonal emotion regulation predict interpersonal competence?

1.2.3 Does emotion dysregulation predict interpersonal competence?

1.2.4 To what extent does interpersonal emotion regulation predict interpersonal competency when controlled for emotion dysregulation?

\section{Method}

\subsection{Participants}

The study sample included 342 (235 female; 107 male) undergraduate students attending various departments of a private university. The departmental distribution of the sample contained 189 students (55.3\%) from the psychological guidance and counseling program, 59 students (17.3\%) from the psychology program, 38 students $(11.1 \%)$ from the international trade program, 27 students $(7.9 \%)$ from the math teaching program, 24 students (6.9\%) from management programs, and 5 students $(1.5 \%)$ from preschool education. The average age of the participants was $20.81(\mathrm{SD}=2.29)$. In order to draw the sample, a convenient sampling method was conducted (Fraenkel, Wallen, \& Hyun, 2011; Shaughnessy, Zechmeister \& Zechmeister, 2015). In this study, convenient sampling method was chosen due to availability and accessibility of the participants and also to get sufficient sample size for the study. The participants completed all of the tests at the same time.

\subsection{Instruments}

2.2.1 Interpersonal Emotion Regulation Questionnaire (Hofmann, Carpenter and Curtis, 2016) was developed to measure interpersonal emotion regulation. The scale was adapted to Turkish by Malkoç, Aslan Gördesli, Arslan, Çekici \& Aydın Sünbül (2018). The scale is made up of 20 items and four sub-scales named as enhancing positive affect, perspective taking, soothing and social modeling. The results of the CFA support the four-factor structure of the scale $(\chi 2 / \mathrm{df}=2.53, \mathrm{p}<.001 ; \mathrm{GFI}=0.90, \mathrm{CFI}=0.94$, TLI $=0.93$, RMSEA $=0.07)$. The internal consistency indicator Cronbach Alpha was calculated .92 for the overall scale. Furthermore, Cronbach alpha values for the sub-scales emerged as .86 for enhancing positive affect, .80 for perspective taking, .88 for soothing and .87 for social modeling. The scale has strong psychometric properties as evident in reliability and validity examination.

2.2.2 The Difficulties in Emotion Regulation Scale (Gratz and Roemer, 2004) is a 36-item measure of the difficulties in regulating emotions. The subscales of DERS include; lack of emotional awareness (6 items), lack of emotional clarity (5 items), non-acceptance of emotional responses (6 items), limited access to emotion regulation strategies (8 items), impulse control difficulties (6 items) and difficulty engaging in goal-directed behavior (5 items). The scale is set out in a 5-point (1-almost never; 5-almost always) Likert type arrangement. The maximum score that can be received from the scale is 180 while the minimum score is 36 . The Cronbach alpha value is .93 for the whole scale and ranges between .80 and .89 for the sub-scales. The Turkish adaptation of DERS yielded a Cronbach alpha value of .94 for the whole scale, while this value ranges between .75 and .90 for the sub-dimensions (Ruganc1, 2008).

2.2.3 The Interpersonal Competency Scale (Buhrmester, Furman, Wittenberg and Reis, 1988) is a self-report inventory to assess interpersonal skills in social relations. The scale is composed of 25 items and 5 sub-dimensions labelled as initiation, emotional support, negative assertion, disclosure and conflict management. The Cronbach alpha values for the subscales range between .74 (disclosure subscale) and .83 (conflict management) and this value is .87 for the whole scale. Test-retest value was found as .89 for the whole scale. The Turkish adaptation also yielded satisfactory reliability evidence for ICS (Şahin and Gizir, 2013). 


\subsection{Data Analysis}

Both pre-analysis and main analysis were conducted via the aid of the SPSS 20 statistical program (IBM, 2011). In the pre-analysis part, missing values, outliers, normality and linearity of the data were examined. After granting satisfactory results for these assumptions, a hierarchical regression analysis along with its major parameters was conducted to examine the relations between interpersonal emotion regulation on interpersonal competency controlled for the effect of difficulties in emotion regulation.

\section{Results}

\subsection{Descriptive Statistics}

Before the main analysis, the descriptive statistics for the variables of the study were explored and given in Table 1.

Table 1. Means, standard deviations and intercorrelations between variables

\begin{tabular}{|c|c|c|c|c|c|}
\hline Variable & M & SD & 1 & 2 & 3 \\
\hline 1.Interpersonal emotion regulation & 70.26 & 14.48 & - & & \\
\hline \multicolumn{6}{|l|}{ 2. Difficulties in emotion regulation } \\
\hline 3. Interpersonal competence & 92.11 & 20.93 & $.19 * * *$ & - & \\
\hline & 85.08 & 14.29 & $.39 * * *$ & $-.17 * *$ & - \\
\hline
\end{tabular}

Note. $\mathrm{N}=342 ; * \mathrm{p}<.05, * * \mathrm{p}<.01, * * * \mathrm{p}<.001$

Given the correlations presented in Table 1, it can be highlighted that there are significantly positive correlations between interpersonal emotion regulation and difficulties in emotion regulation $(\mathrm{r}=.19, \mathrm{p}<.001)$, as well as between interpersonal emotion regulation and interpersonal competence $(r=.39, \mathrm{p}<.001)$. In addition, the correlation between difficulties in emotion regulation and interpersonal competence is significantly negative $(r=-.17, \mathrm{p}<.01)$.

Subsequently, a hierarchical regression analysis was conducted. In the hierarchical regression analysis, the overall fit of the model ( $F$ ratio), effect size for each model, significance of overall model and regression coefficients, squared semi partial correlations, incremental $\mathrm{F}$ values and unstandardized and standardized weights were examined as presented in Table 2 (Tabachnick and Fidell, 2006).

Table 2. Summary of hierarchical regression analysis for the predictors of interpersonal competency $(\mathrm{N}=342)$

\begin{tabular}{|c|c|c|c|c|c|c|c|}
\hline Variable & B & SE B & $\beta$ & $\mathrm{t}$ & $\Delta \mathrm{R}^{2}$ & $\mathrm{R}^{2}$ & $\Delta \mathrm{F}$ \\
\hline Model 1 & & & & & .03 & .03 & $10.39 * *$ \\
\hline 1.Difficulty in emotion regulation & -.12 & .04 & -.17 & $-3.22 * *$ & & & \\
\hline Model 2 & & & & & .18 & .21 & $78.54 * * *$ \\
\hline 1.Difficulty in emotion regulation & -.18 & .03 & -.26 & $-5.22 * * *$ & & & \\
\hline 2.Interpersonal emotion regulation & .43 & .05 & .44 & $8.86 * * *$ & & & \\
\hline
\end{tabular}

Notes. $\mathrm{N}=342 ; * \mathrm{p}<.05, * * \mathrm{p}<.01, * * * \mathrm{p}<.001$

According to Table 2 , the first model significantly predicts interpersonal competency $(\mathrm{F}(1,340)=10.39, \mathrm{p}<.01)$. The adjusted $\mathrm{R}^{2}$ value of .03 shows that difficulties in emotion regulation accounts for $3 \%$ of the variance in interpersonal competency. After controlling for the effect of difficulties in emotion regulation, interpersonal emotion regulation ,as in the second regression model, alone explains $18 \%$ of the overall variance in interpersonal competency and this change in $\mathrm{R}^{2}$ is significant $(\mathrm{F}(1,339)=78.54, \mathrm{p}<.001)$. When individual variables were checked against their unique contributions, as shown in the beta coefficients of the second model, interpersonal emotion regulation $(\beta=.44, t=8.86$, $p<.001)$ proves to have the highest contribution on interpersonal competence, followed by difficulties in emotion regulation. $(\beta=-.26, t=-5.22, p<.001)$. 


\section{Discussion}

The present study controlled the effect of emotion regulation difficulty to analyze the role of interpersonal emotion regulation in interpersonal competence. To this end, first, relations among the three variables were tested. These findings revealed significant relations between the variables. Accordingly, as the ability of interpersonal emotion regulation increases, it appears that so does the participants' interpersonal competence score. Parallel to this, as emotion regulation difficulty increases, interpersonal competence score decreases.

On the other hand, it was found that the higher the emotion regulation difficulty, the higher the ability to regulate interpersonal emotions. This is indicative of the fact that individuals who have difficulty in regulating their own emotions regulate their emotions within the context of social relations with others. In fact, the related literature stresses the importance of the quality and permanence of social relations for emotion regulation (Lopes, Salovey, Cote \& Beers, 2005; Lopes, Salovey, \& Straus, 2003). Moreover, it emphasizes that emotion regulation facilitates initiation and continuation of social interaction (Furr \& Funder, 1998) and that social support, especially from friends and family, contributes to emotion regulation fostering positive emotions (Cohen, 2004; Morris, Silk, Steinberg, Myers, \& Robinson, 2007).

In the second step, predictive power of each variable was computed by regression analysis, which yielded the result that interpersonal emotion regulation is a strong and positive predictor of interpersonal competence. This result points to the strong interpersonal relationships of people who regulate their emotions through other people in the social environment. Some studies have attributed social competence achieved in interpersonal relationships to secure attachment, social support, and emotional support (Baytemir, 2016; Mallinckrodt, 2010). Others have linked parents' behaviors to children's emotion regulation ability and level of social competence (Eisenberg, et al., 2001; McDowell, Kim, O'Neill \& Parkei, 2002). In addition to parental behaviors, negative peer behaviors have been found to have adverse effects on children's both cognitive and affective emotion regulation ability, and on their competence in the social context (Shields, Cicchetti \& Ryan, 1994).

Another finding is that difficulties in emotion regulation prove to be a statistically significant predictor of interpersonal competence. Therefore, it can be concluded that people who have problems in regulating their emotions have low levels of interpersonal competence. Existing studies demonstrate that people who have difficulties in regulating their emotions tend to harm themselves (Gratz \& Roemer, 2008) and display disruptive behaviors (McLaughlin, Hatzenbuehler, \& Hilt, 2009), while also fostering a vulnerability to depression and anxiety (Marganska, Gallagher \& Miranda, 2013). Thus, it is highly likely that these people will face adaptation difficulties in their lives. Miller, Gouley, Seifer, Dickstein \& Shields (2004) believe that the development of emotion regulation skills is integral to children's building healthy relationships with peers and teachers and that activities promoting the acquisition of emotion regulation skills should be included in as early as pre-school or primary school period. Their research revealed that difficulty in regulating emotions impairs children ability to gain social competence.

An analysis of the effect of emotion regulation difficulty showed that skills in interpersonal emotion regulation are a strong predictor of interpersonal competence. This finding confirms that interpersonal emotion regulation is an important variable that accounts for interpersonal competence. This reflects the findings of Ryan, Guardia, Solky-Butzel, Chirkov and Kim (2005), who maintain that emotion regulation has remarkable significance for interpersonal relationships and that people tend to have greater emotional trust towards those who cater for their psychological needs such as autonomy and social competence. They also add that socialization is significant for emotion regulation.

\section{Conclusion}

Many studies point to the relations betweeninterpersonal emotion regulation, emotion regulation dysfunction, and interpersonal competence in children of pre-school, primary, and secondary school age. Therefore, the present study is significant in having widened this scope to young people of university age. However, further research needs to be conducted with sample groups from different age groups and cultures in Turkey. In addition, longitudinal studies should be conducted to shed more light on issues pertaining to interpersonal emotion regulation, interpersonal competence, and emotion dysregulation. Finally, as a result of the findings of this study and others, it is proving highly advisable for psycho-educational programs on emotion regulation be organized and run from university counselling centers to provide support for students who suffer from emotion dysregulation. 


\section{References}

Arnett, J. J. (2000). Emerging adulthood: A theory of development from the late teens through the twenties. American Psychologist, 55, 469-480. https://doi.org/10.1037/0003-066X.55.5.469

Atak, H. \& Çok, F. (2010). A new period in human life: Emerging adulthood. Journal of Childhood and Adolescence Mental Health, 17(1), 39-50.

Baumeister, R. F., \& Leary, M. R. (1995). The Need to Belong: Desire for Interpersonal Attachments as a Fundamental Human Motivation. Psychological Bulletin, 117(3), 497-529. https://doi.org/10.1037/0033-2909.117.3.497

Baytemir, K. (2016). Ergenlikte ebeveyn ve akrana bağlanma ile öznel iyi oluş arasındaki ilişkide kişilerarası yeterliğin arac1lığı. Ĕgitim ve Bilim, 41(186), 69-91.

Berscheid, E. (2003). The Human's Greatest Strength: Other Humans. In: Aspinwall, L.G. and Staudinger, U.M., Eds., A Psychology of Human Strengths, American Psychological Association, Washington DC, 37-48. https://doi.org/10.1037/10566-003

Buhrmester, D. (1990). Intimacy of friendship, interpersonal competence, and adjustment during preadolescence and adolescence. Child Development, 61, 1101-1111. https://doi.org/10.1111/j.1467-8624.1990.tb02844.x

Buhrmester, D. (1998). Need fulfillment, interpersonal competence, and the developmental contexts of early adolescent friendship. In W. M. Bukowski, A. F. Newcomb, \& W. W. Hartup (Eds.), Cambridge studies in social and emotional development. The company they keep: Friendship in childhood and adolescence (pp. 158-185). New York, NY, US: Cambridge University Press.

Buhrmester, D., Furman, W., Wittenberg, W.T., \& Reis, H.T. (1988). Five domains of interpersonal competence in peer relationships. Journal of Personality and Social Psychology, 55(6), 991-1008. https://doi.org/10.1037/0022-3514.55.6.991

Coan, J. A., Schaefer, H. S., \& Davidson, R. J. (2006). Lending a hand: Social regulation of the neural response to threat. Psychological Science, 17, 1032-1039. https://doi.org/10.1111/j.1467-9280.2006.01832.x

Cohen, S. (2004). Social relationships and health. American Psychologist, 59, 676-684. https://doi.org/10.1037/0003-066X.59.8.676

Ehring, T., \& Quack, D. (2010). Emotion regulation difficulties in trauma survivors: the role of trauma type and PTSD symptom severity. Behavior Therapy, 41(4), 587-98. https://doi.org/10.1016/j.beth.2010.04.004

Eisenberg, N., Fabes, R. A., Guthrie, I. K., \& Reiser, M. (2000). Dispositional emotionality and regulation: Their role in predicting quality of social functioning. Journal of Personality and Social Psychology, 78, 136-157. https://doi.org/10.1037/0022-3514.78.1.136

Eisenberg, N., Gershoff, E. T., Fabes, R. A., Shepard, S.A., Cumberland, A. J., Losoya, S. H., Guthrie, I. K., Murphy, B. C. (2001). Mothers' emotional expressivity and children's behavior problems and social competence: mediation through children's regulation. Developmental Psychology, 37(4), 475-90. https://doi.org/10.1037/0012-1649.37.4.475

Foster, S., \& Ritchey, W. L. (1979). Issues in the assessment of social competence in children. Journal of Applied Behavior Analysis, 12(4), 625-638. https://doi.org/10.1901/jaba.1979.12-625

Fraenkel, J., Wallen, N. \& Hyun, H. (2011). How to design and evaluate research in education (8th ed.). US: McGraw-Hill Education.

Furr, R.M., \& Funder, D.C. (1998). A multimodal analysis of personal negativity. Journal of Personality and Social Psychology, 74(6), 1580-1591. https://doi.org/10.1037/0022-3514.74.6.1580

Gratz, K. L., \& Roemer, L. (2004). Multidimensional assessment of emotion regulation and dysregulation: Development, factor structure, and initial validation of the Difficulties in Emotion Regulation Scale. Journal of $\begin{array}{lllll}\text { Psychopathology and } & \text { Behavioral }\end{array}$ https://doi.org/10.1023/B:JOBA.0000007455.08539.94

Gratz, K. L., \& Roemer. L. (2008). The relationship between emotion dysregulation and deliberate self-harm among female undergraduate students at an urban commuter university. Cognitive Behavior Therapy, 37(1), 14-25. https://doi.org/10.1080/16506070701819524 
Higgins, E. T., \& Pittman, T. S. (2008). Motives of the human animal: Comprehending, managing, and sharing inner states. Annual Review of Psychology, 59, 361-385. https://doi.org/10.1146/annurev.psych.59.103006.093726

Hofmann, S. G. (2014). Interpersonal emotion regulation model of mood and anxiety disorders. Cognitive Therapy and Research, 38, 483-492. https://doi.org/10.1007/s10608-014-9620-1

Hofmann, S.G., Carpenter, K., Curtiss, J. (2016). Interpersonal Emotion Regulation Questionnaire (IERQ): Scale development and psychometric characteristics. Cognitive Therapy and Research, 40(3), 341 - 356. https://doi.org/10.1007/s10608-016-9756-2

Hudson, S. M., \& Ward, T. (2000). Interpersonal Competency in Sex Offenders. Behavior Modification, 24(4), 494-527. https://doi.org/10.1177/0145445500244002

IBM Corp. (2011). IBM SPSS statistics for windows. Version 20.0. Armonk. NY: IBM Corp.

Lopes, P. N., Salovey, P., \& Straus, R. (2003). Emotional intelligence, personality, and the perceived quality of social relationships. Personality and Individual Differences, 35, 641-658. https://doi.org/10.1016/S0191-8869(02)00242-8

Lopes, P. N., Salovey, P., Côté, S., Beers, M. (2005). Emotion regulation abilities and the quality of social interaction. Emotion, 5, 113-118. https://doi.org/10.1037/1528-3542.5.1.113

Malkoç, A., Aslan Gördesli, M., Arslan, R., Çekici, F., \& Aydın Sünbül, Z. (2018). The interpersonal emotion regulation scale (IERS): Adaptation and psychometric properties in a Turkish sample. International Journal of Assessment Tools in Education, 5(4), 754 - 762. https://doi.org/10.21449/ijate.481162

Mallinckrodt, B. (2000). Attachment, Social Competencies, Social Support, and Interpersonal Process in Psychotherapy. Psychotherapy Research, 10(3), 239-266. https://doi.org/10.1093/ ptr/10.3.239

Mallinckrodt, B. (2010). The psychotherapy relationship as attachment: Evidence and implications. Journal of Personal and Social Relationships, 27, 262-270. https://doi.org/10.1177/0265407509360905

Marganska, A., Gallagher, M., \& Miranda, R. (2013). Adult attachment, emotion dysregulation, and symptoms of depression and generalized anxiety disorder. The American Journal of Orthopsychiatry, 83(1), 131-41. https://doi.org/10.1111/ajop.12001

Marroquín, B., Tennen, H., \& Stanton, A. L. (2017). Coping, emotion regulation, and well-being: Intrapersonal and interpersonal processes. In M. D. Robinson \& M. Eid (Eds.), The happy mind: Cognitive contributions to well-being (pp. 253-274). Cham, Switzerland: Springer International Publishing. https://doi.org/10.1007/978-3-319-58763-9_14

McDowell, D. J., Kim, M., O'neil, R., \& Parke, R. D. (2002). Children's emotional regulation and social competence in middle childhood: The role of maternal and paternal interactive style. Marriage \& Family Review, 34(3-4), 345-364. https://doi.org/10.1300/J002v34n03_07

McLaughlin ,K. A, Hatzenbuehler, M. L., \& Phil M. (2008). Mechanisms linking stressful events and mental health problems in a prospective, community-based sample of adolescents. Journal of Adolescent Health, 44, 53-160. https://doi.org/10.1016/j.jadohealth.2008.06.019

McLaughlin, K. A., Hatzenbuehler, M. L., \& Hilt, L. M. (2009). Emotion dysregulation as a mechanism linking peer victimization to internalizing symptoms in adolescents. Journal of Consulting and Clinical Psychology, 77(5), 894-904. https://doi.org/10.1037/a0015760

Miller, A. L., Gouley, K. K., Seifer, R., Dickstein, S., \& Shields A. (2004). Emotions and behaviors in the Head Start classroom: Associations among observed dysregulation, social competence, and preschool adjustment. Early Education and Development, 15, 147-165. https://doi.org/10.1207/s15566935eed1502_2

Morris, A. S., Silk, J. S., Steinberg, L., Myers, S. S., \& Robinson, L. R. (2007). The role of the family context in the development of emotion regulation. Social Development, 16, 361-388. https://doi.org/10.1111/j.1467-9507.2007.00389.x

Neumann, A., van Lier, P. A., Gratz, K. L., \& Koo, H. M. (2010). Multidimensional assessment of emotion regulation difficulties in adolescents using the Difficulties in Emotion Regulation Scale. Assessment, 17(1), 138-49. https://doi.org/10.1177/1073191109349579

Niven, K., Totterdell, P., \& Holman, D. (2009). A classification of controlled interpersonal affect regulation strategies. Emotion, 9, 498-509. https://doi.org/10.1037/a0015962 
Rimé, B. (2007). Interpersonal emotion regulation. In J. Gross (Ed.), Handbook of emotion regulation (pp. 466-485). New York, NY: Guilford Press.

Rimé, B. (2009). Emotion elicits the social sharing of emotion: Theory and empirical review. Emotion Review, 1, 60-85. https://doi.org/10.1177/1754073908097189

Roemer, L., Lee, J., Salters-Pedneault, K., Erisman, S., Mennin, D. S., \& Orsillo, S. M. (2009). Mindfulness and emotion regulation difficulties in generalized anxiety disorder: Preliminary evidence for independent and overlapping contributions. Behavior Therapy, 40, 142-154. https://doi.org/10.1016/j.beth.2008.04.001

Rose-Krasnor, L. (1997). The nature of social competence: A theoretical review. Social Development, 6, 111-135. https://doi.org/10.1111/j.1467-9507.1997.tb00097.x

Ruganc1, R. N. (2008). The relationship among attachment style, affect regulation, psychological distress and mental construct of the relational world. (Unpublished PhD Thesis). Orta Doğu Teknik Üniversitesi, Ankara.

Ryan, R. M., La Guardia, J. G., Solky-Butzel, J., Chirkov, V., \& Kim, Y. (2005). On the interpersonal regulation of emotions: Emotional reliance across gender, relationships, and cultures. Personal Relationships, 12(1), 145-163. https://doi.org/10.1111/j.1350-4126.2005.00106.x

Salsman N. L., \& Linehan, M. M. (2012). An investigation of the relationships among negative affect, difficulties in emotion regulation, and features of borderline personality disorder. Journal of Psychopathology and Behavioral Assessment, 34(2), 260-267. https://doi.org/10.1007/s10862-012-9275-8

Shaughessy, J.J., \& Zechmeister, E.B., \& Zechmeister, J.S. (2015). Research Methods in Psychology (p.144). (10 ${ }^{\text {th }}$ Edition). New York: McGrawHill Education.

Shields, A. M., Cicchetti, D., \& Ryan, R. M. (1994). The development of emotional and behavioral self-regulation and social competence among maltreated school-age children. Development and Psychopathology, 6(1), 57-75. https://doi.org/10.1017/S0954579400005885

Şahin, E. E. \& Gizir, C. A. (2013). Kişilerarası Yetkinlik Ölçeği-Kısa formu: Geçerlik ve güvenirlik çalışmaları. Mersin Üniversitesi Ĕ̈itim Fakültesi Dergisi, 9(3), 144-158.

Şahin, E. E. \& Gizir, C. A. (2014). Üniversite Öğrencilerinde Utangaçlık: Benlik Saygısı ve Kişilerarası Yetkinlik Değişkenlerinin Rolü. Türk Psikolojik Danışma ve Rehberlik Dergisi, 5(41), 75-88.

Tabachnick. B. G. \& Fidell. L. S. (2006). Using multivariate statistics (5th ed.). Boston: Allyn and Bacon.

Topping, K., Bremner, W., \& Holmes, E. A. (2000). Social competence: the social construction of the concept. In R. Bar-On, \& J. D. A. Parker (Eds.), The handbook of emotional intelligence: theory, development, assessment, and application at home, school, and in the workplace (pp. 28-39). San Francisco: Jossey-Bass.

Werner, K. H., Goldin, P. R., Ball, T. M., Heimberg, R. G., \& Gross, J. J. (2011). Assessing emotion regulation in social anxiety disorder: The emotion regulation interview. Journal of Psychopathology and Behavioral Assessment, 33(3), 346-354. https://doi.org/10.1007/s10862-011-9225-x

Werner, K. W., \& Gross, J. J. (2009). Emotion regulation and psychopathology: A conceptual framework. In A. Kring $\&$ D. Sloan (Eds.), Emotion regulation and psychopathology. NewYork: Guilford.

Williams, W. C., Morelli, S. A., Ong, D. C., \& Zaki, J. (2018). Interpersonal Emotion Regulation: Implications for Affiliation, Perceived Support, Relationships, and Well-Being. Journal of Personality and Social Psychology, 115(2), 224-254. https://doi.org/10.1037/pspi0000132

Zaki, J., \& Williams, W. C. (2013). Interpersonal emotion regulation. Emotion, 13(5), 803-810. https://doi.org/10.1037/a0033839 